This article is (C) Emerald Publishing and permission has been granted for this version to appear here (repository.falmouth.ac.uk). Emerald does not grant permission for this article to be further copied/distributed or hosted elsewhere without the express permission from Emerald Group Publishing Limited.

\title{
Conspicuous political brand interactions on Social Network Sites
}

\author{
Dr. Ben Marder \\ Business School, University of Edinburgh, UK \\ (Ben.Marder@ed.ac.uk) \\ Dr. Caroline Marchant \\ Business School, University of Edinburgh, UK \\ Prof. Chris Archer-Brown \\ Falmouth University, UK \\ Dr Amy Yau \\ Cardiff Business School, Cardiff University, UK \\ Dr Jonas Colliander \\ Stockholm School of Economics, Sweden
}


This article is (C) Emerald Publishing and permission has been granted for this version to appear here (repository.falmouth.ac.uk). Emerald does not grant permission for this article to be further copied/distributed or hosted elsewhere without the express permission from Emerald Group Publishing Limited.

\section{Purpose}

Acquiring 'Likes' for a political party or candidate's Facebook pages is important for political marketers. For consumers these 'Likes' are conspicuous, making their political affiliation visible to their network. Our study examines the roles of the undesired socialself and visibility (conspicuous vs. inconspicuous) in predicting consumers' intention to 'Like' political brands. We extend knowledge on the undesired social-self, transference of theory from general marketing to a political domain and provide practical advice for political marketers engaging social network sites.

\section{Design/methodology/approach}

We gather data from two surveys run with Facebook using electorates in the run up to the UK 2015 and US 2016 elections $(n=1,205)$ on their intention to 'Like' political brands under different visibility conditions.

\section{Findings}

Data supports the theorized relationship of the undesired social-self with social anxiety intention to 'Like' when 'Liking' is conspicuous. However also 
This article is (C) Emerald Publishing and permission has been granted for this version to appear here (repository.falmouth.ac.uk). Emerald does not grant permission for this article to be further copied/distributed or hosted elsewhere without the express permission from Emerald Group Publishing Limited.

indicates that all users - irrespective of proximity to the undesired social-self - prefer to 'Like' inconspicuously.

Research limitations/implication

The research is limited by the generalizability of the specific context and the use of selfreport measures.

\section{Practical implications}

Political marketers should reconsider promoting conspicuous consumption for that which is more inconspicuous.

\section{Originality}

We provide the first examination of the undesired social-self in driving behavior under different visibility conditions. Furthermore we challenge the extension of existing knowledge of the self-concept within political marketing, based on the 'norm' for consumers' to avoid disclosing political views publically. 
This article is (C) Emerald Publishing and permission has been granted for this version to appear here (repository.falmouth.ac.uk). Emerald does not grant permission for this article to be further copied/distributed or hosted elsewhere without the express permission from Emerald Group Publishing Limited.

Key words: undesired-self, self-concept, political marketing, social network sites, Facebook, social anxiety

\section{Introduction}

Political marketing is no longer a niche curiosity of marketing academics interested in politics but "a significant area of international research in contemporary marketing" (Harris and Lock, 2010, p.297). The transference of general marketing knowledge and techniques is challenging because "a number key differences exist" compared to products and services (Lock and Harris, 1996, p.14). Although valuable work has been undertaken, e.g. Schofield and Reeves' (2015) examination of satisfaction theory in the explanation of voting behavior, further insight is still required. Social network sites (SNS), such as Facebook represent a 'masspersonal' form of communication (O'Sullivan and Carr; 2017) and are crucial marketing platforms, drawing a wealth of scholarly research challenging existing knowledge in this domain (Lawlor et al., 2016). Despite being a key factor in modern elections, relatively scant attention has been given to SNS by political marketing scholars (Noguti, 2016). This study sheds light on this key area of modern political marketing.

A prominent feature of SNS is the conspicuous disclosure of social interaction with brands: liking, sharing, following, posting (Kietzmann et al 2011). Such interactions are visible to users' networks and are a core facet of viral communications leading to SNS 
This article is (C) Emerald Publishing and permission has been granted for this version to appear here (repository.falmouth.ac.uk). Emerald does not grant permission for this article to be further copied/distributed or hosted elsewhere without the express permission from Emerald Group Publishing Limited.

being recognized as the powerhouse of electronic word-of-mouth (e-WOM) (Lindgreen et al, 2013; Koo, 2015).

In political marketing, this mechanism is exploited to spread favorable content to voters. Despite the decline in organic reach on Facebook in recent years, users liking a page is seen by political parties as an important enabler of future direct communication (organic or 'boosted') which is viewed as an important factor in electoral success (Macafee 2013; Hanson et al. 2010). However, in the current platform design, this interaction (referred to as a conspicuous act of 'liking' political brand pages) is visible to the users' extended network, leading to potential influence of peers through public disclosure of users' own political leanings.

However, this may break the social convention of not talking about politics (Starr et al., 2008; Rosenberg, 1954) negatively affecting users' intentions to 'like' political brands' pages. If so, political marketers not only miss out on the viral effects they hope for but also, crucially, miss the opportunity to interact with voters who are genuinely interested in their content, which is a integral part of the democratic process. In the UK $42 \%$ (27 million) of the population are active Facebook users (Fleischmann 2015). In 2017, the Conservatives accumulated 13.6m votes (42.4\%) (BBC News 2017), yet the day before the election their Facebook page had only 634,000 likes. Comparably, The Labour Party, who were second with over $12.9 \mathrm{~m}$ million votes (40.0\%) (BBC News 2017), had less than 300,000 'Likes' (Rothwell 2015). Similarly, in the US, approximately 67\% (163 million) of the adult population are active Facebook users (Gottfried and Shearer 2016). 
This article is (C) Emerald Publishing and permission has been granted for this version to appear here (repository.falmouth.ac.uk). Emerald does not grant permission for this article to be further copied/distributed or hosted elsewhere without the express permission from Emerald Group Publishing Limited.

In July 2016, 4.9 million people 'Liked’ Hillary Clinton's Facebook page and 9.9 million 'Liked' Donald Trump's, representing approximately $1.5 \%$ and $3.1 \%$ of the overall population respectively (DeMers 2016). This illustrates a sizable discrepancy between the number of 'Likes' received by a political brand and the potential market of social media active electorates.

This discrepancy is likely to be partly explained by certain voters who are less politically engaged, having little motivation to 'Like' political entities. However, a further explanation is provided in a study Marder et al (2016) carried out in the run up to the 2015 UK General Election, who propose that the visibility associated with 'Liking' was key in explaining this disparity. They found first, "that conspicuous affiliation with political parties indeed hinders intention to 'Like' political pages and is associated with social anxiety." (p.280). This is a response to the perceived disproval that would occur from their audience if their political viewpoint were to be announced on Facebook. Conversely, consumers showed greater intention to 'Like' a page if it were inconspicuous. Their results suggest that even if a user were motivated to seek political content, their choice of whether to 'Like' or not is influenced by the perceived impact on their external self-representation.

Building this information systems perspective, our theoretical contribution to the political marketing literature is threefold. First, it supports the notion that the conspicuousness of consumption through social media hinders political brand interaction and is associated with social anxiety. In response to recent calls for richer theorization, we adopt an 
This article is (C) Emerald Publishing and permission has been granted for this version to appear here (repository.falmouth.ac.uk). Emerald does not grant permission for this article to be further copied/distributed or hosted elsewhere without the express permission from Emerald Group Publishing Limited.

alternative lens - self-concept, in particular the undesired social-self - which is the negative social state that should be avoided, yet is a key driver in consumer behavior (Bosnjak and Rudolph; 2008). Specifically, we examine the relationship between the proximity to the undesired social-self, social anxiety and the intention to 'Like' pages. Second, we extend knowledge on the choice between conspicuous versus inconspicuous consumption of political brands through Facebook and the role of undesired social-self, through the unique investigation of an interaction effect between the proximity to the undesired social-self (Close vs. Distant) associated with 'Liking' and the consumption condition (Conspicuous vs. Inconspicuous). Third, we provide novel insight into the role of political self-self-consciousness affects 'Liking' when this is conspicuous versus inconspicuous.

Fundamentally, this paper responds to the call for further knowledge on the transference of general marketing theory to political marketing (Lock and Harris, 1996). It examines whether the theorized brand behavior stemming from understanding the self-concept is valid in the political arena given that people may not wish to disclose their political affiliation. Furthermore we contribute practical advice for political marketers investing in social media campaigns.

We investigate a large cross-Atlantic sample in the run up to the $2015 \mathrm{UK}$ General Election and the 2016 US Presidential Election, focusing on political brands to cover both parties and candidates. Extending prior research, we investigate two additional important factors: how ingrained Facebook is in the lives of the electorates and political self- 
This article is (C) Emerald Publishing and permission has been granted for this version to appear here (repository.falmouth.ac.uk). Emerald does not grant permission for this article to be further copied/distributed or hosted elsewhere without the express permission from Emerald Group Publishing Limited.

consciousness.

\section{Background}

\section{Undesired social-self and social anxiety}

Knowledge of the self-concept is valuable to marketers, as endeavors to maintain the 'self' is a strong determinant of decision-making (Grubb and Grathwohl 1967); it is "a system of self schemas or generalizations about the self derived from past social experiences" (Markus and Wurf 1987, p.301). The self-concept is both a dynamic structure and process, where people sustain, develop and reconcile different existing and preferred schemas (Ibid). Levy (1959) introduced the notion of 'self' into the marketing literature, stating that consumers buy products for functional and symbolic qualities that contribute to their self-concept (see also Hamilton and Hassan, 2010).

Research in psychology focused on approaching positive reference points in the selfconcept such as ideal or ought self-guides in driving behavior (Higgins 1987). More recently, researchers have focused on negative self-guides - termed as feared or undesired selves - which individuals endeavor to avoid (Carver, Lawrence and Scheier 1999; Hogg and Banister 2001) and which is a powerful factor in predicting consumer behaviour (Hogg and Bannister 2001).

Relating to low-involvement goods, the effect of undesired selves was better at predicting outcomes than positive self-congruence facets (Bosnjak and Rudolph 2008). Here, the undesired self is characterized as an identity schema, encompassing negatively valenced 
This article is (C) Emerald Publishing and permission has been granted for this version to appear here (repository.falmouth.ac.uk). Emerald does not grant permission for this article to be further copied/distributed or hosted elsewhere without the express permission from Emerald Group Publishing Limited.

traits (e.g. unattractiveness). Undesired selves may include schemas based on a person's own perception, but have a predisposition toward external schemas associated with the social (i.e. expectations of others) given that avoidance based-behavior is more associated with external schemas (Carver, Lawrence and Scheier 1999). As we are examining conspicuous interactions on SNS, to be theoretically distinct from one's own negative self-schemas, we refer to the 'undesired social-self', which is defined as: a collection of negative external self-schemas based on the perceptions of others. Marder et al. (2016) support the use of the undesired social-self in examining SNS phenomena; engagement with Facebook increases public self-awareness, linked with avoidance-based selfregulation (e.g. de-tagging). Using Facebook shifts awareness towards the social (i.e. the expectations of others) thereby, reinforcing that undesired social-selves are likely to be the most salient self-schemas (Carver, Lawrence and Scheier 1999).

An individual's well-being is related directly to the distance from such schemas (Ogilivie 1987). Emotions arise when self-discrepancies exist, given the similarity of the undesired social-self to Higgins' (1987) ought-self (a positive self-state). The emotion arising from an uncomfortable proximity is social anxiety (Higgins 1987), which is the fear of a negative evaluation by others in a current or potential social situation (Leary and Kowalski 1995). The strength of this emotion is also positively related to the distance from the desired state (Higgins 1987).

Conspicuous interactions on SNS

Conspicuous consumption focuses on understanding how people express social status 
This article is (C) Emerald Publishing and permission has been granted for this version to appear here (repository.falmouth.ac.uk). Emerald does not grant permission for this article to be further copied/distributed or hosted elsewhere without the express permission from Emerald Group Publishing Limited.

through brand affiliation (Mason 1984; Veblen 1899). Recently, technological advancements have facilitated this: SNS's allow users to visibly interact with one another and with brands, contributing to their self-concept (Taylor et al, 2016). Through SNS, brands offer consumers symbolic material to maintain their self-concept in just a few clicks (Hollenbeck and Kaikati 2012). Belk (2013) suggests that the relationship between physical / digital possessions and the real / digital self are similar..

Researchers have uncovered mixed consumer attitudes on this topic: Hollenbeck and Kaikati (2012) investigated how brand engagement on Facebook contributed to users' self-concept, finding that individuals connect only with brands that are congruent with their actual or ideal selves. However, their study focused on positive guiding selves, neglecting the role of the undesired selves. The increased visibility of gift giving through SNS, caused by greater density in social ties, resulted in a reduction of gift purchase due to increased scrutiny and social surveillance (Shmargad and Watts, 2016). Importantly, conspicuous consumption on SNS largely occurs in the presence of 'context collapse', where interactions are viewed simultaneously by an imagined audience of multiple others with different expectations of a desired image (Marwick and Boyd, 2011; Vitak, 2012). Context collapse constrains people's self-present, e.g. self-censoring tweets (Marwick and Boyd, 2011). However, Hayes et al (2015) found that greater friend numbers did not hinder political disclosure on Facebook. These studies highlight that conspicuousness of brand interactions on SNS may hinder the likelihood they will occur in the first place.

These findings are congruent with recent works on inconspicuous consumption which is 
This article is (C) Emerald Publishing and permission has been granted for this version to appear here (repository.falmouth.ac.uk). Emerald does not grant permission for this article to be further copied/distributed or hosted elsewhere without the express permission from Emerald Group Publishing Limited.

noted to be subtle and not readily observable to others, if at all (Berger and Ward 2010). Affluent westerners prefer to show status more subtly through inconspicuous consumption differentiating themselves from those in 'new wealth' who favour conspicuous consumption (Eckhardt, Belk and Wilson 2015).

Taking into account idiosyncrasies of political marketing (Shephard and Quinlan, 2016), we propose a three-fold rationale for why the conspicuousness of interacting with political brands is a pressing issue: (1) political affiliation is important within a person's self-concept (Smith and French 2009); (2) people tend not to want to expose their political affiliation publically (e.g. Starr et al., 2008); (3) SNS are critical platforms for contemporary political marketing, particularly campaign participation (Aldrich et al., 2016).

Conspicuous interactions, social anxiety and 'liking'

SNS have been found in recent years to be important for marketers as tools for increasing political participation (Cogburn and Espinoza-Vasquez, 2011; Towner and Muñoz, 2016), micro-targeting specific electorate (Newman, 2016), creating a space for dialogue (Enli and Skogerbø, 2013) and as a means for shaping the brand image of political entities (Colliander et al., 2017). This study is concerned with the conspicuous act of 'liking' US and UK political brands on Facebook in the lead up to the 2015 UK General Election and the 2016 US Presidential Election. Notwithstanding the advantages, such as entertainment, information, identity affirmation (Macafee 2013; Hanson et al. 2010), both UK and US political brands have received fewer 'likes' than might be anticipated. We 
This article is (C) Emerald Publishing and permission has been granted for this version to appear here (repository.falmouth.ac.uk). Emerald does not grant permission for this article to be further copied/distributed or hosted elsewhere without the express permission from Emerald Group Publishing Limited.

use self-concept theory to develop Marder et al's (2016) notion that the conspicuous nature of 'Liking' deters people. Although, voters may have some motivation to 'like' a political party, they may chose not to because of the social anxiety related to the visible nature of 'Liking' and a desire to avoid projecting an undesired social-self to their imagined audience, which is likely to suffer from context collapse.

Facebook usage increases public self-awareness (Marder et al, 2016b) and makes salient an individuals' undesired social-self and the comparison of one's current self with this negative reference point (Carver, Lawrence and Scheier, 1999). Increased proximity from the undesired-self means a greater distance between the public image a person projects and what image is undesired in the minds of their audience (Bosnjak and Rudolph, 2008). If too close, social anxiety arises negatively proportionate to the proximity from the undesired social-self (Higgins, 1987; Leary and Kowalksi, 1995). Thus:

H1: Increased proximity to the undesired social-self resultting from having conspicuously 'Liked' political brands' Facebook pages is positively related to social anxiety.

To avoid a negative self-portrayal online and the associated social anxiety, voters may avoid 'Liking' political brands Facebook pages. Lending support to this notion are the findings of Carver and Scheier (2001), who assert that people use self-regulation to avoid congruence with negative self-states (see also Carver, Lawrence and Scheier, 1999; Leary, 1995). This leads to: 
This article is (C) Emerald Publishing and permission has been granted for this version to appear here (repository.falmouth.ac.uk). Emerald does not grant permission for this article to be further copied/distributed or hosted elsewhere without the express permission from Emerald Group Publishing Limited.

H2: Increased proximity to the undesired social-self is negatively related to the intention to conspicuously 'Like' political brands' Facebook pages.

Drawing from Marder et al (2016) our underlying notion is that social anxiety mediates the relationship between the increased proximity to the undesired social-self and the intention to conspicuously 'like' a political brand's Facebook page as follows. Consequently:

H3: The relationship between proximity to the undesired social self and intention to conspicuously 'Like' political brands' Facebook pages is mediated by social anxiety.

To understand the impact of visibility on the likelihood of user interaction and the efficacy of the existing marketing knowledge of the self-concept in the political arena, it is imperative to contrast the conspicuous status quo with a scenario where such interaction is inconspicuous. The option to inconspicuously 'like' a political brand's Facebook page, would eliminate the risk of projecting an undesired social-self, but would allow the potential advantages such as entertainment, information or identity affirmation for the user and a means of direct communication for marketers (Macafee 2013; Hanson et al. 2010). Prior work by Marder et al (2016) found electorates had a higher intention to inconspicuously 'Like' compared to when this was conspicuous. However, this did not investigate the role of the undesired social-self in this difference in intention over two visibility conditions. Prior work in the field of marketing would predict this to be important in understanding consumer choice in this context (Bosnjak and Rudolph, 
This article is (C Emerald Publishing and permission has been granted for this version to appear here (repository.falmouth.ac.uk). Emerald does not grant permission for this article to be further copied/distributed or hosted elsewhere without the express permission from Emerald Group Publishing Limited.

2008). Although, Hogg and Banister's (2001) research on the undesired-self and consumer choice has suggested "visibility" (i.e. public vs. private) of consumption is important in consumer decision-making, they call for further insights.

People associate with products/brands that support their actual-self "approach", create a desired self-state and avoid brands that would increase congruence with a negative-state e.g. the undesired social-self (Sirgy, 1982, p.290). Consumers who believe that others will view their affiliation with a brand favorably will want to display it whereas those who imagine it will cast a negative image to others will not (Hollenbeck and Kaikati, 2012; Solomon et al, 2012; Hamilton and Hassan, 2010). Thus we predict that:

H4: Proximity to the undesired social-self(close vs. distant) will interact with the visibility level (conspicuous vs. inconspicuous). When the proximity is close and the 'Like' is conspicuous, intention to 'Like' will be lower vs. when the proximity is distant and the 'Like' is conspicuous. In contrast when the proximity is close and the 'Like is inconspicuous, intention to 'Like' will be higher vs. when the proximity is distant and the 'Like' is inconspicuous.

Public self-consciousness or the awareness of oneself as a social object (Fenigstein, Scheier and Buss, 1975) (especially in a political context), is important here. Through understanding the impact of this construct on 'liking' behavior we are able consider to the notion that people are weary of revealing their political affiliation (Starr et al., 2008, p.259; Rosenberg, 1954). Extant research asserts that more self-conscious individuals are motivated to enhance or protect their public persona (White and Peloza, 2009). Thus: 
This article is (C) Emerald Publishing and permission has been granted for this version to appear here (repository.falmouth.ac.uk). Emerald does not grant permission for this article to be further copied/distributed or hosted elsewhere without the express permission from Emerald Group Publishing Limited.

H5: Increased political self-consciousness is associated with a greater intention to 'Like' a political brand inconspicuously versus conspicuously.

\section{Methodology}

\section{Participants and Procedure}

We developed two online surveys, adopting purposive sampling of eligible voters who were also Facebook users, before the 2015 UK General Election and 2016 US Presidential Election. In both surveys, confirmed they met the selection criteria. UK survey participants were recruited through links to the survey in discussions on Facebook that were initiated by national news brands (e.g. Guardian, The Times), as well as email lists and social media accounts associated with three Universities in the UK. A small monetary donation to one of three well-known charities was offered. Data collection started one-month prior the UK General Election on 7 May 2015 and ceased one week before the Election. The US survey was released through Amazon Mechanical Turk, a commonly used tool for survey responses in the field of interactive marketing (Labrecque, 2014), which has been found to have significantly fewer issues with nonresponse error compared to other studies gathering participant from web pools such as forums (Paolacci, Chandler and Ipeirotis, 2010). The survey was open to US participants. To reduce social desirability bias, the sample included only workers with a validated track record in over 50 past surveys and participants were assured that the survey was anonymous (Peer, Vosgerau, and Acquisti, 2014; Huang, 2006). Qualtrics was used to publish the survey and measures were in place to avoid multiple responses from the same 
This article is (C) Emerald Publishing and permission has been granted for this version to appear here (repository.falmouth.ac.uk). Emerald does not grant permission for this article to be further copied/distributed or hosted elsewhere without the express permission from Emerald Group Publishing Limited.

participant. Data collection started 23 August 2016 and finished on the 3 September 2016.

Purposive methods are acceptable where criteria are objectively set and supported by the context (e.g. eligible voters / Facebook users). Typically, purposive sampling leads to non-generalizable findings beyond the sample (Black 1999). However, following the reasoning of Calder et al (1981), we maintain that theoretical generalizations are possible, where limitations are noted. First, it is impossible to acquire population lists of Facebook users who are also eligible voters in order to perform randomized sampling (Tow, Dell and Venable 2010). Second, this is consistent with sampling procedure for populations of adult Internet users (e.g. Park, Shin and Ju 2015; Marder et al., 2016b).

\section{Measures}

The surveys involved three core measures proximity to the undesired social self, perceived from being seen to have liked a political party on Facebook, associated social anxiety, and intention to 'Like'. These constructs were measured in conjunction with the act of 'Liking' the Facebook brand page of either the two most popular UK parties (Conservatives and Labour) or the two candidates in the US 2016 Presidential Election: Hillary Clinton and Donald Trump. If a respondent stated that they had already 'Liked' one or both of these respective brands, related questions where skipped. Data pertaining to each of the four brands were combined for each construct. Multiple level randomization was set up to avoid order bias, specifically the order of the two political brands were randomized, as well as the presentation of the intention to 'Like' conditions 
This article is (C) Emerald Publishing and permission has been granted for this version to appear here (repository.falmouth.ac.uk). Emerald does not grant permission for this article to be further copied/distributed or hosted elsewhere without the express permission from Emerald Group Publishing Limited.

(conspicuous vs. inconspicuous) within.

To measure proximity to the undesired social self, participants were asked the following question: "Imagine the scenario where you have 'Liked' [political party's] Facebook page and evidence of this has become visible to your Facebook 'friends'. Please indicate along the scale what image of yourself you consider this would portray to others". Adapted from Ajzen and Driver (1992), five-items, reported along a 7-point Likert scale (e.g. desired-undesired), were employed $\alpha<.07$ for all four political brands, (see Table 1 for factor loadings). A higher score represents that 'Liking' the page is closer to the undesired social-self.

To evaluate social anxiety, participants where asked how they would feel if others saw that they had 'Liked' the [brand's] Facebook page. Adapted from Feldman (1995), fouritems were employed, scored along a 7-point scale (e.g. Calm-Tense), <.07 for all four political brands, (see Table 1 for factor loadings). A higher score infers greater social anxiety.

Intention to 'Like' was evaluated under two scenarios. First, the real life condition whereby 'When you click 'Like' on the [political party's or candidate's] Facebook page it will be visible to your friends". Second, a hypothetical 'Secret Like' which "would NOT be made visible to your Facebook friends". The sequence in which these scenarios were presented was randomized and a verification question validated that the sentiment of each scenario was understood. Adapted from Bosnjak and Rudolph (2008), the Intention to 'Like' employed two items, answered along a 7-point scale (Very 
This article is (C) Emerald Publishing and permission has been granted for this version to appear here (repository.falmouth.ac.uk). Emerald does not grant permission for this article to be further copied/distributed or hosted elsewhere without the express permission from Emerald Group Publishing Limited.

Unlikely - Very Likely), $\alpha$ (visible) and $\alpha$ (secret) $<.07$ for all four political brands (see Table 1 for factor loadings). After each visibility condition for each political brand was presented (along with their subsequent measures), a verification question was presented. Participants were asked whether the answers given were dependent on whether the 'Like' of the political party/candidate was based on being secret or visible to their Facebook friends. A higher score for the intention to 'Like' scale represents a greater intention to 'Like'.

Political self-consciousness was assessed through a 3-item scale adapted from Fenigstein, Scheier and Buss (1975) to examine political consciousness on Facebook (e.g. my friends' and colleagues' opinions about me liking a candidate's Facebook page would cause me concern). This was scored along a 7-point scale (strongly disagree - strongly agree) $[\alpha=.85 \mathrm{UK}, .90 \mathrm{US}]$. A higher score indicates an increased level of political public self-consciousness.

Control Variables. It was crucial that respondents were motivated to some extent to 'Like' the party pages. If participants had no motivation, we could not claim that concerns related to their social self-concept inhibited their intention to 'Like'. An adapted version of Hanson et al.'s (2010) scale was used to measure motivation to 'Like' each of the party's pages: 10-items, scored along a 7-point scale (strongly disagree - strongly agree), $[\alpha=.88$ UK, .90 US]. A higher score represents a higher motivation. Furthermore participants' political orientation was measured using Mehrabian's (1996) 7-item scale (conservativism - liberalism). This was measured using a 7-point Likert 
This article is (C) Emerald Publishing and permission has been granted for this version to appear here (repository.falmouth.ac.uk). Emerald does not grant permission for this article to be further copied/distributed or hosted elsewhere without the express permission from Emerald Group Publishing Limited.

scale (strongly disagree - strongly agree) [ $\alpha=.89$ UK, .91 US]. A higher score signifies a greater orientation towards conservatism. Facebook usage intensity was measured through the scale created by Ellison et al. (2007) this involves 7 items, measured along 7point scale (strongly disagree- strongly agree) scales and the additional item of number of Facebook friends was standardized to seven points, $(\alpha=0.78 \mathrm{UK}, .80 \mathrm{US})$. A higher score signifies higher usage intensity. Participants also reported their gender, age and if they used privacy settings to restrict visibility of all pages 'Liked' (Appendix A).

\section{Results}

The UK survey was completed by 225 participants and the US survey by 980 participants. Following exclusions: (1) those who had already 'Liked' at least one of the political brands; (2) those who showed no motivation to 'Like' a political brand: (3) those who employed privacy settings that prevented their network seeing 'Likes': (4) those who failed one of the condition verification questions (15\%), samples were: UK $n=169$; US $n$ $=429$ for each political brand, in total $\mathrm{n}=1,196$.

UK survey participants were $57 \%$ female with a mean age of 28.4 years $(S D=10.5)$. 97\% percent resided in the UK. $47 \% / 52 \%$ of respondents were in full-time education/employment respectively. In the US survey respondents were $66 \%$ female with a mean age of $36.7(S D=12.5), 59.7 \%$ were full-time employed, $16.5 \%$ part-time, $12.6 \%$ unemployed and the remainder students and retirees. Overall both samples had a slightly liberal leaning, the UK/US scored $3.12(S D=1.53) / 3.40(S D=.1 .38)$ respectively (central = 4). Harman's single factor test tested for possible presence of Common Method 
This article is (C) Emerald Publishing and permission has been granted for this version to appear here (repository.falmouth.ac.uk). Emerald does not grant permission for this article to be further copied/distributed or hosted elsewhere without the express permission from Emerald Group Publishing Limited.

Bias and 30\% of variance was explained by a single factor, well below the threshold for establishing that bias was absent. The US and UK samples were tested for equivalence through a series of independent sample t-tests as suggested by Weber and Popova (2012), for the majority of the constructs equivalence was maintained at the guide threshold delta of Cohens $d=.2$ (Stegner, Bostrom and Greenfield, 1996), however for certain constructs equivalence was uncertain. Therefore, a 'dataset control variable' was created to control for and interpret nonequivalence, which may be due to the nature of brands being either political parties or candidates, or the country of origin (Davis, 2008). Constructs approximated a normal distribution apart from intention to 'Like' in both visible and secret scenarios, which had a positive skew. Although a cause for some caution, the tests are considered robust given the large sample size. Tests were carried out in line with Speed (1994) and outlined in table 1. 
This article is (C) Emerald Publishing and permission has been granted for this version to appear here (repository.falmouth.ac.uk). Emerald does not grant permission for this article to be further copied/distributed or hosted elsewhere without the express permission from Emerald Group Publishing Limited.

Table 1 - Regression Analysis

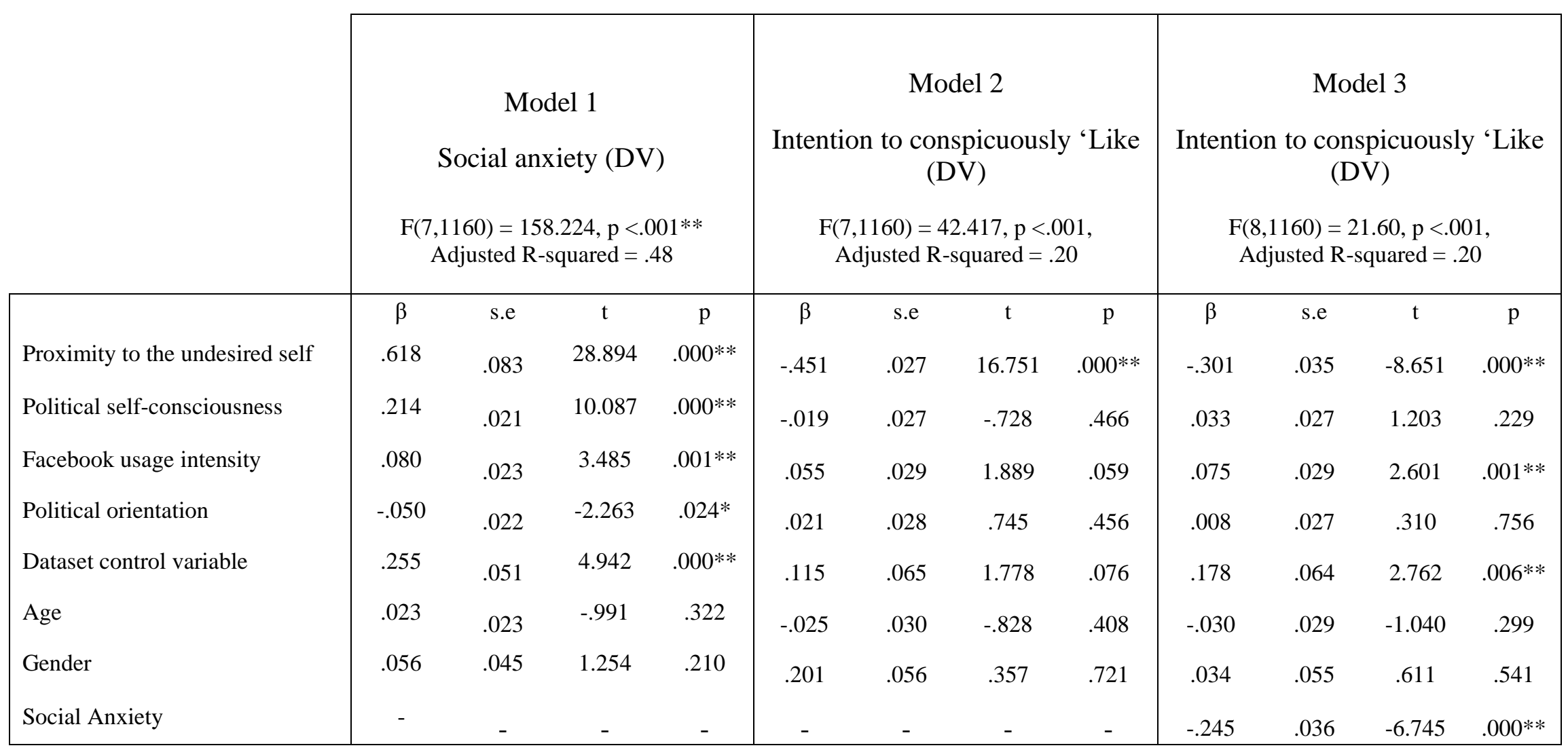

$* \mathrm{p}<.05, * * \mathrm{p}<.01$ (Two-tailed) 
This article is (C) Emerald Publishing and permission has been granted for this version to appear here (repository.falmouth.ac.uk). Emerald does not grant permission for this article to be further copied/distributed or hosted elsewhere without the express permission from Emerald Group Publishing Limited.

Undesired self and conspicuous 'Liking' of Political brands (H1-H3)

Mediation analysis using Preacher and Hayes (2008) bootstrapping method ( $\mathrm{n}=10.000)$ chosen to overcome the limitations of previous methods (Zhao, Lynch and Chen 2009). Proximity to the undesired self was entered as the independent variable $(I V)$, social anxiety the mediator $(M)$ and intention to 'Like' the party's Facebook page (taken from the conspicuous 'Like' condition) as the dependent variable $(D V)$. Political self-consciousness, Facebook usage intensity, political orientation, gender, dataset control variable and age were added as covariates. The bootstrap method provides three regressions and a bootstrapped coefficient for the $M$, overall allowing for the testing of $\mathrm{H} 1-\mathrm{H} 3$. Model 1, regresses the $I V$ on $M$ testing $\mathrm{H} 1$ and providing the pathway (a). Model 2, regresses the $I V$ on the $D V$ providing total effect $(c)$ testing $\mathrm{H} 2$. Model 3 regresses both the $I V$ and $M$ on the $D V$, providing the direct effect (ć) $\left[\beta_{I V}\right]$ and $(b)\left[\beta_{M}\right]$. A bootstrapped analysis of the product of $a$ and $b$ provides a confidence interval which allows for the determination of the indirect effect, addressing H3. Collinearity statistics were checked for all regression analyses; VIF statistics were satisfactory as all were below 2 (Hair, Ringle and Sarstedt 2011). A correlation matrix is provided in Appendix B. Possible heteroscedasticity was assessed through inspections of QQ plots, due to the nature of the inferential tests being sensitive to deviations in normality, the the plots were satisfactory (Hall 1987).

H1 is supported as the proximity to the undesired social-self positively predicts social anxiety, $\beta=.618, \mathrm{p}<.01$ (Model 1). Note that a higher value for proximity to the undesired social-self means a closer proximity (i.e. a worse image to others). This shows that people perceive conspicuous 'Liking' of a political brand on Facebook casts a worse image (i.e. is closer to their 
This article is (C) Emerald Publishing and permission has been granted for this version to appear here (repository.falmouth.ac.uk). Emerald does not grant permission for this article to be further copied/distributed or hosted elsewhere without the express permission from Emerald Group Publishing Limited.

undesired social-self). A greater level of social anxiety is predicted to take place if this behavior occurred.

$\mathrm{H} 2$ is supported as proximity to the undesired self negatively predicts intention to 'Like' , $\beta$ $=-.451, \mathrm{p}<.01$ (Model 2). When participants perceived that the 'Liking' of a political brand's Facebook page approaches an undesired social-self intention to 'Like', the page is reduced.

The bootstrapped confidence interval (95\%) for indirect effect (ab) shows that social anxiety is a significant mediator between proximity to the undesired-self and intention to 'Like' (i.e. the confidence interval does not cross zero) [Lower -.198, Upper -.110]. H3 is thus supported. Inspection of Model 3 allows us to conclude that the mediation is complementary (sometimes termed partial) (Baron \& Kenny, 1986; Zhao, Lynch and Chen 2010). Comparing Models 3 with 2, shows the coefficient for the proximity to the undesired social self decreases from -.451 to .301 and in both cases it remains significant $(\mathrm{p}<.01)$.

Model 1 revealed a positive relationship between political self-consciousness and social anxiety ( $\beta=.214, \mathrm{p}<.01)$. Model 1 further showed significant relationship between Facebook usage intensity and social anxiety $(\beta=.080, \mathrm{p}<.01)$. Model 3 found Facebook usage intensity positively predicts intention to 'Like' $(\beta=.075, \mathrm{p}<.01)$ when social anxiety is controlled for. In addition, the dataset control variable was significant in model 1 and $3(\mathrm{p}<.01)$ with a positive coefficient suggesting that the US sample have higher anxiety associated with 'Liking' a political brand and also higher intention to 'Like' (when anxiety is controlled for) compared to the UK sample. Political orientation was significant in Model $1(\mathrm{p}<.05)$ with a negative 
This article is (C) Emerald Publishing and permission has been granted for this version to appear here (repository.falmouth.ac.uk). Emerald does not grant permission for this article to be further copied/distributed or hosted elsewhere without the express permission from Emerald Group Publishing Limited.

coefficient suggesting increased liberalism coincides with lower social anxiety. Age and gender had no significant effect in the model.

Conspicuous vs. Inconspicuous 'Liking' (H4-H5)

A mixed-model ANCOVA was employed to address H4 (Table 2). The within-subject factor visibility consisted of two levels: conspicuous 'Like' vs secret 'Like'. The between-subject factor proximity is a dichotomization of the proximity to the undesired social-self variable, creating two levels 'close' to the undesired self and 'distant'. The split was carried out on the basis that the central node (four) in the original semantic differential scales represents a neutral image to others. Participants who scored $\geq 3$ were considered distant whereas those $\leq 5$ close to their undesired social-self. Using an ANCOVA and a binary proximity variable provides intuitive findings that are more easily decipherable with regards to contrasting conspicuous versus inconspicuous conditions. We acknowledge the drawbacks of dichotomizing variables and provide further regression analysis to support the findings of the above, with the undesired social-self as continuous variable (Cohen 1983; Royston Altman and Sauerbrei 2006) (Table 3).

Facebook usage intensity, political self-consciousness, the dataset variable, age, and gender were entered as control variables. As the Box-M test for homogeneity of covariance matrices was significant $(\mathrm{p}<.01)$, Pillai Trace correction was applied. The findings showed that the mean intention to 'Like' differed significantly across the two visibility levels, participants showed a higher intention to 'Like' the 'secret' page ( $\mathrm{MD}=.776, \mathrm{p}<.01)$. In support of $\mathrm{H} 4$ the interaction between visibility condition and proximity was significant $(p<.05)$. Figure 2 illustrates the nature of this interaction. Although intention to 'Like' was greater when it was secret over both 
This article is (C) Emerald Publishing and permission has been granted for this version to appear here (repository.falmouth.ac.uk). Emerald does not grant permission for this article to be further copied/distributed or hosted elsewhere without the express permission from Emerald Group Publishing Limited.

proximity levels, the difference between the visibility levels was less when the proximity was close. Visibility also provided significant interactions with Facebook usage intensity $(\mathrm{p}<.01)$, political self-consciousness $(\mathrm{p}<.01)$ and political orientation $(\mathrm{p}<.05)$. The three-way interaction between visibility, the dataset control variable and proximity was also significant $(\mathrm{p}<.05)$.

Table 2 - Mixed-Model ANCOVA

\begin{tabular}{lccc}
\hline Within-subject effects & F $(12,714)$ & Significance & Partial Eta \\
\hline Visibility & 6.726 & $.001 * *$ & .010 \\
Visibility * Proximity & 4.440 & $.035 *$ & .006 \\
Visibility * Usage Intensity & 10.164 & $.001 *$ & .014 \\
Visibility * Political self-con & 38.849 & $.000 * *$ & .052 \\
Visibility * Pol orientation & 5.225 & $.023 *$ & .007 \\
Visibility * Dataset control & .137 & .711 & .000 \\
Visibility * Age & .037 & .852 & .000 \\
Visibility * Gender & 1.921 & .166 & .003 \\
Visibility * Gender * Dataset & .000 & .988 & .000 \\
Visibility * Gender * Proximity & .320 & .571 & .000 \\
Visibility *Dataset * Proximity & 3.84 & $.049 *$ & .005 \\
Vis * Gender* Prox * Dataset & .245 & .641 & .000 \\
\hline *p<.05, * p<.01 & & & \\
\hline
\end{tabular}


This article is (C) Emerald Publishing and permission has been granted for this version to appear here (repository.falmouth.ac.uk). Emerald does not grant permission for this article to be further copied/distributed or hosted elsewhere without the express permission from Emerald Group Publishing Limited.

Figure 2 - Interaction effects

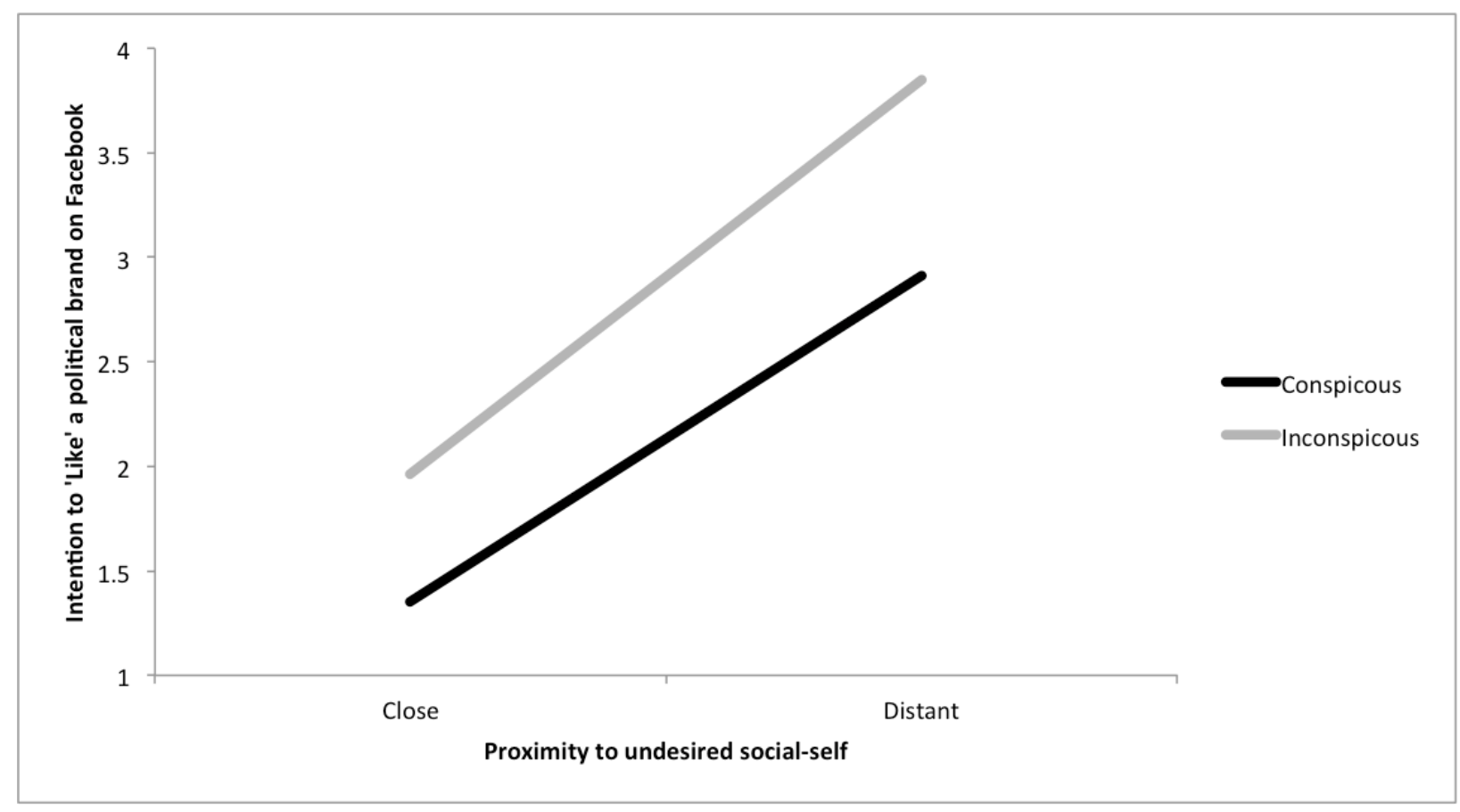

A multiple regression analysis was carried out using the dependent variable difference between the intention to 'Like' across the two visibility levels (conspicuous - inconspicuous). The main IV of interest is proximity to the undesired social-self. Political self-consciousness, Facebook usage intensity, gender, age, the dataset control variable and political orientation were added as controls. Assumptions were checked and were satisfactory. This provided further support for H4 
This article is (C) Emerald Publishing and permission has been granted for this version to appear here (repository.falmouth.ac.uk). Emerald does not grant permission for this article to be further copied/distributed or hosted elsewhere without the express permission from Emerald Group Publishing Limited.

as proximity to the undesired social-self was a negative predictor of the differences in 'Like' intention across visibility levels $(\beta=-.143, \mathrm{p}<.01)$. Increased political self-consciousness $(\beta$ $=.217, \mathrm{p}<.01)$ was found to increase the difference intention between 'Liking' political brands across the two visibility conditions, supporting H5, that more self-conscious individuals are more inclined to like inconspicuously. Facebook usage intensity $(\beta=.104, \mathrm{p}<.01)$ was also a positive predictor for difference in 'Like' intention: the more intense or politically selfconscious the user, the more inclined they are towards inconspicuous 'Liking'. There were no further significant effects of the control variables.

Table 3: Intention over secret vs. visible 'Liking'

\begin{tabular}{lccc}
\hline & $\begin{array}{c}\beta \text { Standardized } \\
\text { (S.E) }\end{array}$ & $\mathrm{t}$ & Significance \\
\hline Proximity to the undesired self & $-.143(.027)$ & -4.977 & $.000^{* *}$ \\
Political self-consciousness & $.217(.025)$ & 8.832 & $.000^{* *}$ \\
Facebook usage intensity & $.104(.033)$ & 3.664 & $.000^{* *}$ \\
Political orientation & $.045(.030)$ & 1.600 & .110 \\
Dataset control variable & $.007(.101)$ & .216 & .829 \\
Age & $.022(.003)$ & .735 & .463 \\
Gender & $.034(.088)$ & 1.175 & .240 \\
\hline $\mathrm{F}(7,1160)=18.126, \mathrm{p}<.001$, Adjusted R-squared $=.09 . * \mathrm{p}<.05, * * \mathrm{p}<.01$ (Two-tailed) &
\end{tabular}

\section{Discussion}

Overall the findings contribute valuable knowledge for political marketers on the role of 
This article is (C) Emerald Publishing and permission has been granted for this version to appear here (repository.falmouth.ac.uk). Emerald does not grant permission for this article to be further copied/distributed or hosted elsewhere without the express permission from Emerald Group Publishing Limited.

visibility of political brand interaction through SNS. Most notably, that existing knowledge of self-concept within marketing is challenged by social norms of disclosure of political affiliation. Furthermore, our research contributes to calls from marketing scholars for further investigation into the undesired-social within the social self-concept (Bosnjak and Rudolph 2008; Hogg and Bannister 2001; Hassan and Hamilton 2010). We found that the perceived proximity to the undesired social-self from the action of 'Liking' a brand is positively related to the magnitude of social anxiety caused, which is in line with Marder et al (2016). Further, proximity to the undesired social-self has a negative impact on intention to conspicuously 'Like' a brand, a relationship mediated by social anxiety. As the size of this effect fell when social anxiety was accounted for, but still remained significant, this suggests only partial mediation and therefore the existence of other possible mediators. One such variable may be 'expectancy' i.e. perceived likelihood that 'Liking' the brand will actually be seen by specific Facebook friends or generally on the site (Carver and Scheier 2001; Leary and Kowalski 1995). The association between the undesired-self, social anxiety and avoidance-based behavior concurs social psychological perspectives (Higgins, 1987; Leary 1996) and supports Bosnjak and Rudolph's (2008), argument for the need for marketers not just to consider positive self-guides but also the commonly neglected negative reference points.

Contrasting conspicuous versus inconspicuous behaviour with brand interactions on SNS, we support Marder et al's (2016), finding that people show a greater intention to 'Like' a political brand privately (i.e. inconspicuous), also that visibility hinders brand interaction (Shmargad and Watts 2016). However in contrast to prior knowledge of the self-concept was the lack of interaction between visibility levels (conspicuous versus inconspicuous) and the proximity to the 
This article is (C) Emerald Publishing and permission has been granted for this version to appear here (repository.falmouth.ac.uk). Emerald does not grant permission for this article to be further copied/distributed or hosted elsewhere without the express permission from Emerald Group Publishing Limited.

undesired social-self (close versus distant). Based on existing social psychological and marketing theory, we would have expected that if 'Liking' a brand makes one appear favourable to others, users would be more inclined to 'Like' conspicuously than inconspicuously, and vice versa. However, the crux of our results find that people prefer to 'Like' political brands secretly, irrespective of how their audience would perceive them if this was done visibly.

We propose this novel finding might be partially explained by the existence of context collapse and the notion that a 'lowest-common denominator' effect occurs in the presence of multiple audiences with diverse standards (Marwick and Boyd, 2011; Vitak, 2012). Although largely 'Liking' a political party may be distant from an undesired social-self, for certain audiences this may not be the case and therefore inconspicuous is preferred. However, we believe our finding is more likely explained by people not wanting to project their political affiliations in public (Starr et al., 2008, Rosenberg, 1954). Our regression in Table 3 provides support for this proposal, showing that electorates who are more self-conscious of exposing to others their political views reported a greater intention towards 'Liking' inconspicuously. These findings highlight an important difference in consumer behaviour related to political brands versus general brands, adding to those noted by Lock and Harris (1996). Unlike the normal scenario where if a brand makes you look good 'flaunt it'; for political brands this is not the case. This suggests that generally accepted theorized brand behaviour stemming from knowledge of the self-concept (Sirgy, 1982), found to previously hold for general consumption through SNS (Hollenbeck and Kaikati 2012), might be contradicted by a social norm of non-disclosure associated with political brands. 
This article is (C) Emerald Publishing and permission has been granted for this version to appear here (repository.falmouth.ac.uk). Emerald does not grant permission for this article to be further copied/distributed or hosted elsewhere without the express permission from Emerald Group Publishing Limited.

We do not suggest that self-concept theory itself does not hold for this phenomenon, but that the general viewpoint of consumer behavior theorists is challenged in the political context. Further research should be conducted into possible differences between the political self-concept and the more general consumer self-concept. Researchers may locate the salient schemas (e.g. norms of expression, disclosure) that drive public affiliation with political brands. In addition future research could examine the impact and boundary conditions of the prevailing norm for consumers not to disclose their political inclination. It is also important to note that in response to Hogg and Banister's (2001) call for understanding the visibility of consumption driven by the undesired-self, our research provides valuable insight into the area of political marketing. Findings here should not be considered for more general marketing phenomena given the nuanced contextual elements of this study discussed above. Thus, we add to the call for work into the visibility within undesired-self related consumption.

We note a significant interaction between proximity to the undesired social-self and visibility level, albeit with a relatively weak effect size (Partial Eta $=.006)$. Supported by the additional regression, there is a greater difference between intention to 'Like' conspicuously versus inconspicuously when it is perceived that doing so would portray a more positive impression. We believe this finding influenced by the congruence between one's own beliefs and that represented by the brand, rather than social selves. It is known that people's own values often align with those of their friends (Jussim and Osgood 1989), therefore we can assume that a close proximity to the undesired social-self mirrors the distant proximity to one's own ideal-self. Consequently, intention to 'Like' in either visibility condition reduces. In contrast, if the person felt that 'Liking' a brand was favourable, both to themselves and to others, then there would be a 
This article is (C) Emerald Publishing and permission has been granted for this version to appear here (repository.falmouth.ac.uk). Emerald does not grant permission for this article to be further copied/distributed or hosted elsewhere without the express permission from Emerald Group Publishing Limited.

greater intention to 'Like'.

We found that higher levels of political self-consciousness increased social anxiety associated with 'Liking' a political brand (Fenigstein, Scheier and Buss 1975; Leary and Kowalski 1995), although no direct effect was found on the intention to 'Like' the brand conspicuously. Political marketers may consider the level of self-consciousness of their audiences, in order to minimise social anxiety, especially in SNS's, which promote high visibility.

Facebook usage intensity was found to positively predict social anxiety, being negatively associated with intention to conspicuously 'Like' and positively related to inconspicuous 'Liking'. Pettijohn et al (2012) found that usage intensity was related to the need for social approval, supporting the positive relationship with social anxiety. However, it contrasts with Maksl and Young's (2013) findings, where intense users were more comfortable posting information for others to see. Although more intense users feel more anxious about the audience, they are more likely to 'Like' more pages anyway. Interestingly, they would still opt for the ability to secretly 'Like'.

Prior findings that show little significance difference in the patterns of Facebook usage by US and UK users (Vasalou, Joinson and Courvoisier, 2010). In contracst, in the context of 'Liking' political brands, US users exhibited greater anxiety and a lower intention to 'Like'. We cannot tell from the data whether this is due to cultural differences or associated with the potential to 'Like' candidates rather than parties; this could be addressed by further research. However we propose that this difference may be explained by the polemic nature of Trump and Clinton combined with the presence of context collapse. In other words, affiliating with one candidate 
This article is (C) Emerald Publishing and permission has been granted for this version to appear here (repository.falmouth.ac.uk). Emerald does not grant permission for this article to be further copied/distributed or hosted elsewhere without the express permission from Emerald Group Publishing Limited.

may generate the potential for repercussions from opposing audiences than would supporting either of the UK political parties which at the time of the 2015 election were less divergent.

The present study has several strengths. First, it employs well-established theories develop hypotheses to support political marketing research. Second, it carries out data collection on electorate Facebook users at a pivotal time for engaging with political brands. Third, checks were employed to ensure all consumers in the sample were somewhat motivated to 'Like' the political brands to safeguard that the visibility conditions were interpreted correctly. Finally, a rigorous multi-level randomization process was adopted to avoid order bias whilst still allowing for benefits of within-subject analyses; this overcomes issues with individual differences (Poulton 1982). Nevertheless, limitations are also recognized.

First, although intention scales and correlation-based analysis are widely used in consumer behavior research (e.g. Archer-Brown et al 2017) we suggest future research employing laboratory experiments should be used to address the limitations of self-report intention scales and possible endogeneity (Podaksoff and Organ 1986). Second, additional moderating variables and covariates may examine intention to 'Like' conspicuously as well as to explore the difference between conspicuous and inconspicuous behaviour. Specifically based on the findings of Goodwin (1992), further studies should assess the impact of individual level selfmonitoring. Third, further research can examine the interplay of intrinsic approach based guides (e.g. ideal-self) with the undesired social-self in predicting 'Like' behavior. Fourth, our attention was on Facebook as this is the most well-used SNS; different sites will vary with regards to the conspicuousness of interactions as well diversity of the audience, so we suggest replication of 
This article is (C) Emerald Publishing and permission has been granted for this version to appear here (repository.falmouth.ac.uk). Emerald does not grant permission for this article to be further copied/distributed or hosted elsewhere without the express permission from Emerald Group Publishing Limited.

our study in other platforms. Finally, controlled laboratory based experiments may be used to further investigate the novel finding here that existing knowledge on the self-concept for marketers is challenged when applied to political consumer behaviour.

Our research makes three theoretical contributions. On Facebook, where brand interactions are mostly conspicuous, the undesired social-self plays an important role in understanding consumers' intention to interact with political brands. Specifically, people are motivated to maintain distance from the undesired social-self in choosing to interact conspicuously with branded content. Thus if an interaction is perceived to project an image that is proximal to the undesired social-self, intention for this interaction will be varied, in order to maintain congruence with the expectations of their audience.

When the choice of an inconspicuous form of consuming political brands on Facebook is introduced, the role of undesired-social self-associated with the symbolic value linked directly with the political brand, asserted by prior research to guide consumption decisions, is diminished. We propose this is overridden by the social norm that dictates one should avoid public disclosure of political affiliation. This is supported by our third contribution, that people who are more publically self-consciousness about exposing their political views to others favour 'Liking' inconspicuously.

In response to calls for further understanding for the undesired social-self and transference of existing knowledge from the general marketing domain to the study of political marketing, we 
This article is (C) Emerald Publishing and permission has been granted for this version to appear here (repository.falmouth.ac.uk). Emerald does not grant permission for this article to be further copied/distributed or hosted elsewhere without the express permission from Emerald Group Publishing Limited.

support the general theorized relationship of the undesired social-self on the premise that consumption is conspicuous. However, we challenge the transference of this theory to political marketing when there is the option to consume political brands inconspicuously, proposing that social norms associated with disclosing political affiliation highlight an important difference in the political versus general marketing domain.

\section{Managerial Implications}

Whether leveraging organic reach or buying exposure, political marketers should reconsider campaigns focused solely on gathering 'Likes'. Marketers should instead opt for call-to-action campaigns based on 'signing up', where users can provide their email address as means of receiving brand information privately, away from the gaze of their audience. Sign-up buttons can be added to targeted materials as well as the page itself. However, given the possible low intention to 'Like' certain brands conspicuously and due to 'Like' campaigns being the 'pay per Like' of many campaigns, they may be poor at gathering 'Likes' despite being a cost effective way to gain impressions. More generally, political marketers should be mindful of their audiences' audience in all their content marketing aims and objectives, adding a further check box for approval before content goes live.

Designers at Facebook and other SNS, should consider an affordance that allows subscription through site itself without the public and visible connection. It warrants investigation into the 
This article is (C) Emerald Publishing and permission has been granted for this version to appear here (repository.falmouth.ac.uk). Emerald does not grant permission for this article to be further copied/distributed or hosted elsewhere without the express permission from Emerald Group Publishing Limited.

benefits for users, brands and the platform for maximizing conspicuous interactions across networks. Furthermore, users' concerns about visible affiliation should be incorporated in the content provision algorithm: emphasizing that exposure should be taken from visible interactions such as 'Liking' and given to other inconspicuous actions such as repeated searching, click-through and subscriptions. Designers at SNS should also test out the different terms commonly used for the gateway interaction function (e.g. follow, subscribe, Like), as it is likely that level of affinity associated with words such as 'Like' will be greater than words such as 'subscribe' thereby shedding more light on how conspicuous brand linkages are perceived.

\section{References}

Ajzen, I. \& Driver, B. (1992). Contingent value measurement: On the nature and meaning of willingness to pay. Journal of Consumer Psychology, 1(4), 297-316.

Archer-Brown, C., Kampani, J., Marder, B., Bal, A. S., \& Kietzmann, J. (2017). Conditions in Prerelease Movie Trailers For Stimulating Positive Word of Mouth. Journal of Advertising Research, 57(2), 159-172.

Aldrich, J. H., Gibson, R. K., Cantijoch, M., \& Konitzer, T. (2016). Getting out the vote in the social media era: Are digital tools changing the extent, nature and impact of party contacting in elections?. Party Politics, 22(2), 165-178.

Baron, R. M. \& Kenny, D. A. (1986). The moderator, mediator variable distinction in social psychological research: Conceptual, strategic, and statistical considerations. Journal of Personality And Social Psychology, 51(6): 1173.

BBC News. (2015). Conservatives win 12-seat majority, Election 2015: Results. http://www.bbc.co.uk/news/election/2015/results accessed on 11.5.16 
This article is (C) Emerald Publishing and permission has been granted for this version to appear here (repository.falmouth.ac.uk). Emerald does not grant permission for this article to be further copied/distributed or hosted elsewhere without the express permission from Emerald Group Publishing Limited.

Belk, R. W. (2013). Extended self in a digital world. Journal of Consumer Research, 40(3), 477500.

Berger, J. \& Ward, M. (2010). Subtle signals of inconspicuous consumption. Journal of Consumer Research, 37(4), 555-569.

Black, T. (1999). Doing Quantitative Research in the Social Sciences: An Integrated Approach to Research Design, Measurement and Statistics, London, UK: SAGE

Bosnjak, M. \& Rudolph, N. (2008). Undesired self-image congruence in a low-involvement product context. European Journal of Marketing, 42(5/6), 702-712.

Calder, B. J., Phillips, L. W. \& Tybout A. M. (1981) Designing Research for Application. Journal of Consumer Research. 8(2), 197-207.

Carver, C. S. \& Scheier, M. F. (2001). On the self-regulation of behavior. Cambridge University Press.

Carver, C. S., Lawrence, J. W. \& Scheier, M. F. (1999). Self-discrepancies and affect: Incorporating the role of feared selves. Personality and social psychology bulletin, 25(7), 783792.

Cogburn, D. L., \& Espinoza-Vasquez, F. K. (2011). From networked nominee to networked nation: Examining the impact of Web 2.0 and social media on political participation and civic engagement in the 2008 Obama campaign. Journal of Political Marketing, 10(1-2), 189-213.

Cohen, J. (1983). The cost of dichotomization. Applied Psychological Measurement, 7: 249-253,

Colliander, J., Marder, B., Falkman, L. L., Madestam, J., Modig, E., \& Sagfossen, S. (2017). 
This article is (C) Emerald Publishing and permission has been granted for this version to appear here (repository.falmouth.ac.uk). Emerald does not grant permission for this article to be further copied/distributed or hosted elsewhere without the express permission from Emerald Group Publishing Limited.

The social media balancing act: Testing the use of a balanced self-presentation strategy for politicians using twitter. Computers in Human Behavior, 74, 277-285.

Davis, S. F. (Ed.). (2008). Handbook of research methods in experimental psychology. John Wiley \& Sons.

DeMers, J. (2016). Donald Trump vs Hillary Clinton whos winning at online marketing. Accessed 12/7/16 at http://www.forbes.com/sites/jaysondemers/2016/07/28/donald-trump-vshillary-clinton-whos-winning-at-online-marketing/\#6dfde76f7861

Eckhardt, G. M., Belk, R. W. \& Wilson, J. A. (2015). The rise of inconspicuous consumption. Journal of Marketing Management, 31(7-8), 807-826.

Ellison, N. B., Steinfield, C. \& Lampe, C. (2007). The benefits of Facebook "friends:" Social capital and college students use of online social network sites. Journal of Computer-Mediated Communication, 12, 1143-1168.

Enli, G. S., \& Skogerbø, E. (2013). Personalized campaigns in party-centred politics: Twitter and Facebook as arenas for political communication. Information, Communication \& Society, 16(5), 757-774.

Feldman, L. A. (1995). Variations in the circumplex structure of mood. Personality and Social Psychology Bulletin 21(8), 806-817.

Fenigstein, A., Scheier, M. F. \& Buss, A. H. (1975). Public and private self-consciousness: Assessment and theory. Journal of consulting and clinical psychology, 43(4), 522.

Fleischmann, C. (2015). UK Digital, Social and Mobile Statistics for 2015 \#smlondon. Accessed 12/6/15 at http://socialmedialondon.co.uk/digital-social-mobile-statistics-2015/ 
This article is (C) Emerald Publishing and permission has been granted for this version to appear here (repository.falmouth.ac.uk). Emerald does not grant permission for this article to be further copied/distributed or hosted elsewhere without the express permission from Emerald Group Publishing Limited.

Goodwin, C. (1992). A conceptualization of motives to seek privacy for nondeviant consumption. Journal of Consumer Psychology, 1(3), 261-284.

Gottfried, J. \& Shearer, E. (2016). News Use Across Social Media Platforms 2016 Accessed 13.6.16 at http://www.journalism.org/2016/05/26/news-use-across-social-media-platforms$2016 /$

Grubb, E. L. \& Grathwohl, H. L. (1967). Consumer self-concept, symbolism and market behavior: A theoretical approach. The Journal of Marketing, 22-27.

Hair, J. F., Ringle, C. M. \& Sarstedt, M. (2011). PLS-SEM: Indeed a silver bullet. Journal of Marketing Theory and Practice, 19(2), 139-152.

Harris, P. \& Lock, A. (2010). "Mind the gap": the rise of political marketing and a perspective on its future agenda. European Journal of Marketing, 44(3/4), 297-307.

Hall, A. (1987). The information matrix test for the linear model. The Review of Economic Studies, 54(2), 257-263.

Hamilton, K., \& Hassan, L. (2010). Self-concept, emotions and consumer coping: Smoking across Europe. European Journal of Marketing, 44(7/8), 1101-1120.

Hanson, G., Haridakis, P. M., Cunningham, A. W., Sharma, R. \& Ponder, J. D. (2010). The 2008 presidential campaign: Political cynicism in the age of Facebook, MySpace, and YouTube. Mass Communication and Society, 13(5), 584-607.

Huang, H. M. (2006). Do print and Web surveys provide the same results?. Computers in Human Behavior, 22(3), 334-350.

Higgins, E. T. (1987). Self-discrepancy: a theory relating self and affect. Psychological review, 94(3), 319. 
This article is (C) Emerald Publishing and permission has been granted for this version to appear here (repository.falmouth.ac.uk). Emerald does not grant permission for this article to be further copied/distributed or hosted elsewhere without the express permission from Emerald Group Publishing Limited.

Hogg, M. K. \& Banister, E. N. (2001). Dislikes, distastes and the undesired self:

Conceptualising and exploring the role of the undesired end state in consumer experience.

Journal of Marketing Management, 17(1-2), 73-104.

Hayes, R. A., Smock, A., \& Carr, C. T. (2015). Face [book] management: Self-presentation of political views on social media. Communication Studies, 66(5), 549-568.

Hollenbeck, C. R. \& Kaikati, A. M. (2012). Consumers' use of brands to reflect their actual and ideal selves on Facebook. International Journal of Research in Marketing 29(4), 395-405.

Jussim, L. \& Osgood, D. W. (1989). Influence and similarity among friends: An integrative model applied to incarcerated adolescents. Social Psychology Quarterly, 98-112.

Kietzmann, J.H., Hermkens, K., McCarthy, I.P. and Silvestre, B.S. (2011). Social media? Get serious! Understanding the functional building blocks of social media. Business horizons, 54(3), 241-251.

Koo, D. M. (2015). The strength of no tie relationship in an online recommendation: Focused on interactional effects of valence, tie strength, and type of service. European Journal of Marketing, 49(7/8), 1163-1183.

Labrecque, L. I. (2014). Fostering consumer-brand relationships in social media environments: The role of parasocial interaction. Journal of Interactive Marketing, 28(2), 134-148.

Lawlor, M. A., Lawlor, M. A., Dunne, Á., Dunne, Á., Rowley, J. \& Rowley, J. (2016). Young consumers' brand communications literacy in a social networking site context. European Journal of Marketing, 50(11), 2018-2040. 
This article is (C) Emerald Publishing and permission has been granted for this version to appear here (repository.falmouth.ac.uk). Emerald does not grant permission for this article to be further copied/distributed or hosted elsewhere without the express permission from Emerald Group Publishing Limited.

Leary, M. R. (1996). Self presentation: Impression management and interpersonal behavior, Westview Press.

Leary, M. R. \& Kowalski, R. M. (1995). Social anxiety. New York, Guilford Press

Levy, S. J. (1959). Symbols for sale. Harvard business review, 37(4), 117-124.

Lindgreen, A., Dobele, A. \& Vanhamme, J. (2013). Word-of-mouth and viral marketing referrals: what do we know? and what should we know. European Journal of Marketing, 47(7), 1028-1033.

Lock, A. \& Harris, P. (1996). Political marketing-vive la difference! European Journal of marketing, 30(10/11), 14-24.

Macafee, T. (2013). Some of these things are not like the others: Examining motivations and political predispositions among political Facebook activity. Computers in Human Behavior 29(6): 2766-2775.

Maksl, A. \& Young, R. (2013). Affording to exchange: social capital and online information sharing. Cyberpsychology, Behavior, and Social Networking, 16(8), 588-592.

Marder, B., Slade, E., Houghton, D., \& Archer-Brown, C. (2016). "I like them, but won't 'like'them": An examination of impression management associated with visible political party affiliation on Facebook. Computers in Human Behavior, 61, 280-287.

Marder, B., Houghton, D., Joinson, A., Shankar, A. \& Bull, E. (2016b). Understanding the Psychological Process of Avoidance-Based Self-Regulation on Facebook. Cyberpsychology, Behavior, and Social Networking, 19(5), 321-327. 
This article is (C) Emerald Publishing and permission has been granted for this version to appear here (repository.falmouth.ac.uk). Emerald does not grant permission for this article to be further copied/distributed or hosted elsewhere without the express permission from Emerald Group Publishing Limited.

Markus, H. \& Wurf, E. (1987). The dynamic self-concept: A social psychological perspective. Annual review of psychology, 38(1), 299-337.

Marwick, A. E \& Boyd, D. (2011). I tweet honestly, I tweet passionately: Twitter users, context collapse, and the imagined audience. New Media \& Society, 13(1) 114-133

Mason, R. (1984). Conspicuous consumption: A literature review. European Journal of Marketing, 18(3), 26-39.

Mehrabian, A. (1996). Relations among political attitudes, personality, and psychopathology assessed with new measures of libertarianism and conservatism. Basic and Applied Social Psychology, 18(4), 469-491.

Newman, B. I. (2016). Reinforcing Lessons for Business from the Marketing Revolution in US Presidential Politics: A Strategic Triad. Psychology \& Marketing, 33(10), 781-795.

Noguti, V. (2016). Post language and user engagement in online content communities. European Journal of Marketing, 50(5/6), 695 - 723

Ogilvie, D. M. (1987). The undesired self: A neglected variable in personality research. Journal of Personality and Social Psychology, 52(2), 379-385.

Paolacci, G., Chandler, J. \& Ipeirotis, P. G. (2010). Running experiments on amazon mechanical turk. Judgment and Decision making, 5(5), 411-419.

Park, M. S., Shin, J. K. \& Ju, Y. (2015). A Taxonomy of Social Networking Site Users: Social Surveillance and Self - surveillance Perspective. Psychology \& Marketing, 32(6), 601-610.

Peer, E., Vosgerau, J., \& Acquisti, A. (2014). Reputation as a sufficient condition for data quality on Amazon Mechanical Turk. Behavior research methods, 46(4), 1023-1031. 
This article is (C) Emerald Publishing and permission has been granted for this version to appear here (repository.falmouth.ac.uk). Emerald does not grant permission for this article to be further copied/distributed or hosted elsewhere without the express permission from Emerald Group Publishing Limited.

Pettijohn, T. F., LaPiene, K. E. \& Horting, A. L. (2012). Relationships between facebook intensity, friendship contingent self-esteem, and personality in US college students.

Cyberpsychology, 6(1), 1-7.

Podsakoff, P. \& Organ, D. (1986). Self-reports in organizational research: Problems and prospects. Journal of management, 12(4), 531-544.

Poulton, E. (1982). Influential companions: Effects of one strategy on another in the withinsubjects designs of cognitive psychology. Psychological Bulletin, 91(3), 673-690.

Preacher, K. \& Hayes, A. (2008). Asymptotic and resampling strategies for assessing and comparing indirect effects in multiple mediator models. Behavior research methods, 40(3), 879891.

Rosenberg, M. (1954). Some determinants of political apathy. Public Opinion Quarterly, 18(4), 349-366.

Rothwell, J. (2015). Election 2015: Which party won the social media war? The Telegraph. Accessed 6/5/15 at http://www.telegraph.co.uk/news/general-election-2015/11585233/Election2015-Which-party-has-won-the-social-media-war.html

Royston, P., Altman, D. G. \& Sauerbrei, W. (2006). Dichotomizing continuous predictors in multiple regression: a bad idea. Statistics in medicine, 25(1), 127-141.

O’Sullivan, P. B., \& Carr, C. T. (2017). Masspersonal communication: A model bridging the mass-interpersonal divide. New Media \& Society, 1461444816686104. 
This article is (C) Emerald Publishing and permission has been granted for this version to appear here (repository.falmouth.ac.uk). Emerald does not grant permission for this article to be further copied/distributed or hosted elsewhere without the express permission from Emerald Group Publishing Limited.

Shephard, M., \& Quinlan, S. (2016). Social media and the Scottish independence referendum 2014: Events and the generation of enthusiasm for yes. The Routledge companion to social media and politics, 488-502.

Schofield, P., \& Reeves, P. (2015). Does the factor theory of satisfaction explain political voting behaviour?. European Journal of Marketing, 49(5/6), 968-992.

Shmargad, Y. \& Watts, J. K. (2016). When Online Visibility Deters Social Interaction: The Case of Digital Gifts. Journal of Interactive Marketing, 36, 1-14.

Sirgy, M. J. (1982). Self-concept in consumer behavior: A critical review. Journal of consumer research, 9(3), 287-300.

Smith, G., \& French, A. (2009). The political brand: A consumer perspective. Marketing theory, 9(2), 209-226.

Solomon, M., Russell-Bennett, R. \& Previte, J. (2012). Consumer behaviour. Pearson Higher Education AU.

Starr, A., Fernandez, L. A., Amster, R., Wood, L. J. \& Caro, M. J. (2008). The impacts of state surveillance on political assembly and association: A socio-legal analysis. Qualitative Sociology, 31(3), 251-270.

Speed, R. (1994). Regression type techniques and small samples: A guide to good practice. Journal of Marketing Management, 10(1-3), 89-104.

Stegner, B. L., Bostrom, A. G. \& Greenfield, T. K. (1996). Equivalence testing for use in psychosocial and services research: An introduction with examples. Evaluation and Program Planning, 19(3), 193-198. 
This article is (C) Emerald Publishing and permission has been granted for this version to appear here (repository.falmouth.ac.uk). Emerald does not grant permission for this article to be further copied/distributed or hosted elsewhere without the express permission from Emerald Group Publishing Limited.

Taylor, D. G., Strutton, D. \& Strutton, D. (2016). Does Facebook usage lead to conspicuous consumption? The role of envy, narcissism and self-promotion. Journal of Research in Interactive Marketing, 10(3), 231-248.

Tow, W. N. F. H., Dell, P. \& Venable, J. (2010). Understanding information disclosure behavior in Australian Facebook users. Journal of Information Technology, 25(2), 126-136.

Towner, T. L., \& Muñoz, C. L. (2016). Baby boom or bust? The new media effect on political participation. Journal of Political Marketing, 1-30.

Vasalou, A., Joinson, A. N., \& Courvoisier, D. (2010). Cultural differences, experience with social networks and the nature of "true commitment" in Facebook. International journal of human-computer studies, 68(10), 719-728.

Veblen, T. (1899). The Theory Of The Leisure Class. New York: The New American Library.

Vitak, J (2012). The Impact of Context Collapse and Privacy on Social Network Site Disclosures. Journal of Broadcasting \& Electronic Media, Vol. 56 , Iss. 4,2012

Weber, R. \& Popova, L. (2012). Testing equivalence in communication research: Theory and application. Communication Methods and Measures, 6(3), 190-213.

White, K., \& Peloza, J. (2009). Self-benefit versus other-benefit marketing appeals: Their effectiveness in generating charitable support. Journal of Marketing, 73(4), 109-124.

Zhao, X., Lynch, J. G. \& Chen, Q. (2010). Reconsidering Baron and Kenny: Myths and truths about mediation analysis. Journal of Consumer Research, 37(2), 197-206. 
This article is (C) Emerald Publishing and permission has been granted for this version to appear here (repository.falmouth.ac.uk). Emerald does not grant permission for this article to be further copied/distributed or hosted elsewhere without the express permission from Emerald Group Publishing Limited.

\section{Appendix A - Survey Details}

\begin{tabular}{|c|c|c|c|c|c|c|c|c|c|c|c|c|c|c|c|c|}
\hline \multirow[b]{2}{*}{ Construct } & \multicolumn{4}{|c|}{ Donald Trump } & \multicolumn{4}{|c|}{ Hillary Clinton } & \multicolumn{4}{|c|}{ Labour Party } & \multicolumn{4}{|c|}{ Conservative Party } \\
\hline & $M$ & $S D$ & Load & $\alpha$ & $M$ & $S D$ & Load & $\alpha$ & $M$ & $S D$ & Load & $\alpha$ & $M$ & $S D$ & Load & $\alpha$ \\
\hline \multicolumn{17}{|c|}{ Proximity to the undesired social-self Please indicate along the scale what image of yourself you consider this would portray to others. } \\
\hline 1. Pleasant-Unpleasant & 5.7 & 1.6 & .96 & .97 & 4.5 & 1.5 & .95 & .97 & 3.8 & 1.3 & .89 & .93 & 5.2 & 1.5 & .92 & .95 \\
\hline 2. Positive - Negative & 5.7 & 1.6 & .97 & & 4.4 & 1.6 & .97 & & 3.9 & 1.3 & .89 & & 5.2 & 1.5 & .92 & \\
\hline 3. Good-Bad & 5.6 & 1.6 & .97 & & 4.4 & 1.6 & .96 & & 3.7 & 1.2 & .92 & & 5.2 & 1.5 & .94 & \\
\hline 4. Attractive - Unattractive & 5.6 & 1.6 & .96 & & 4.5 & 1.5 & .95 & & 4.2 & 1.1 & .85 & & 5.0 & 1.4 & .91 & \\
\hline 5. Desired-Undesired & 5.6 & 1.6 & .96 & & 4.6 & 1.5 & .95 & & 4.2 & 1.2 & .86 & & 5.1 & 1.5 & .91 & \\
\hline \multicolumn{17}{|c|}{ Social anxiety Please indicate how you would feel if your Facebook friends saw that you had 'Liked' [Candidate/ Party] Facebook page: } \\
\hline 1. Happy - Unhappy & 5.4 & 1.6 & .86 & .93 & 4.5 & 1.5 & 8.3 & 9.4 & 4.3 & 1.5 & .79 & .93 & 5.3 & 1.5 & .76 & .93 \\
\hline 2. Relaxed-Anxious & 5.1 & 1.7 & .97 & & 4.3 & 1.7 & 9.5 & & 4.7 & 1.6 & .96 & & 4.4 & 1.7 & .96 & \\
\hline 3. Calm-Tense & 5.1 & 1.8 & .97 & & 4.1 & 1.7 & 9.6 & & 3.6 & 1.6 & .94 & & 4.3 & 1.7 & .97 & \\
\hline 4. Not-worried-Worried & 5.0 & 1.9 & .96 & & 3.9 & 1.8 & 9.4 & & 3.5 & 1.7 & .93 & & 4.2 & 1.8 & .94 & \\
\hline \multicolumn{17}{|c|}{$\begin{array}{l}\text { Visible 'Like' When you click 'Like' on [Candidate/ Party] Facebook page it will be VISIBLE to your 'friends', please indicate the likelihood you would do the foll } \\
\text { before the [Date Presidential/General] Election: }\end{array}$} \\
\hline 1. Click 'Like' on the page & 1.6 & 1.2 & .95 & .89 & 2.1 & 1.5 & .95 & .89 & 2.1 & 1.5 & .94 & .87 & 1.6 & 1.2 & .90 & .83 \\
\hline 2. Receive updates from [Candidate/ Party] from 'Liking' the pag & 1.7 & 1.5 & .95 & & 2.2 & 1.7 & .95 & & 2.2 & 1.6 & .94 & & 1.8 & 1.3 & .90 & \\
\hline \multicolumn{17}{|c|}{$\begin{array}{l}\text { Secret 'Like' Based on your 'Like' being SECRET, please indicate with regards to [Candidate/ Party] Facebook page the likelihood you would do the following be } \\
\text { the [Date Presidential/General] Election: }\end{array}$} \\
\hline 1. Click 'Like' on the page & 2.1 & 2.1 & .96 & .92 & 2.8 & 2.3 & 9.7 & .93 & 2.9 & 2.0 & .97 & .93 & 2.4 & 1.9 & .96 & .92 \\
\hline 2. Receive updates from [Candidate/ Party] from 'Liking' the pag & 2.2 & 2.1 & .96 & & 2.9 & 2.3 & 9.7 & & 2.8 & 1.9 & .97 & & 2.5 & & .96 & \\
\hline
\end{tabular}


This article is (C) Emerald Publishing and permission has been granted for this version to appear here (repository.falmouth.ac.uk). Emerald does not grant permission for this article to be further copied/distributed or hosted elsewhere without the express permission from Emerald Group Publishing Limited.

\section{Appendix B}

\begin{tabular}{|c|c|c|c|c|c|c|c|c|c|c|}
\hline & 1 & 2 & 3 & 4 & 5 & 6 & 7 & 8 & 9 & 10 \\
\hline $\begin{array}{l}\text { 1. Proximity to the } \\
\text { undesired social-self }\end{array}$ & & & & & & & & & & \\
\hline $\begin{array}{l}\text { 2. Political self- } \\
\text { consciousness }\end{array}$ & $\begin{array}{l}.002 \\
(.937)\end{array}$ & & & & & & & & & \\
\hline $\begin{array}{l}\text { 3. Facebook usage } \\
\text { intensity }\end{array}$ & $\begin{array}{l}-.015 \\
(.603)\end{array}$ & $\begin{array}{l}.258^{* * *} \\
(.000)\end{array}$ & & & & & & & & \\
\hline 4. Political orientation & $\begin{array}{l}-.058^{*} \\
(.045)\end{array}$ & $\begin{array}{l}.134^{* * *} \\
(.000)\end{array}$ & $\begin{array}{l}.087^{* *} \\
(.003)\end{array}$ & & & & & & & \\
\hline 5. Dataset control variable & $\begin{array}{l}.194^{* * *} \\
(.000)\end{array}$ & $\begin{array}{l}.079^{* *} \\
(.006)\end{array}$ & $\begin{array}{l}.073^{*} \\
(.011)\end{array}$ & $\begin{array}{l}.090^{* *} \\
(.002)\end{array}$ & & & & & & \\
\hline 6. Age & $\begin{array}{l}.015 \\
(.615)\end{array}$ & $\begin{array}{l}.091^{* *} \\
(.002)\end{array}$ & $\begin{array}{l}.103^{* * *} \\
(.000)\end{array}$ & $\begin{array}{l}.110^{* *} \\
(.000)\end{array}$ & $\begin{array}{l}.371^{* * *} \\
(.000)\end{array}$ & & & & & \\
\hline 7. Gender & $\begin{array}{l}.036 \\
(.221)\end{array}$ & $\begin{array}{l}.050 \\
(.002)\end{array}$ & $\begin{array}{l}.188^{* * *} \\
(.000)\end{array}$ & $\begin{array}{l}.081^{* *} \\
(.005)\end{array}$ & $\begin{array}{l}.073^{*} \\
(.012)\end{array}$ & $\begin{array}{l}.047 \\
(.111)\end{array}$ & & & & \\
\hline 8. Social anxiety & $\begin{array}{l}.656^{* * *} \\
(.353)\end{array}$ & $\begin{array}{l}.132^{* * *} \\
(.000)\end{array}$ & $\begin{array}{l}.071^{*} \\
(.014)\end{array}$ & $\begin{array}{l}-.059^{*} \\
(.042)\end{array}$ & $\begin{array}{l}.195^{* * *} \\
(.000)\end{array}$ & $\begin{array}{l}.014 \\
(.634)\end{array}$ & $\begin{array}{l}.078^{* *} \\
(.007)\end{array}$ & & & \\
\hline $\begin{array}{l}\text { 9. Intention to } \\
\text { conspicuously 'Like' }\end{array}$ & $\begin{array}{l}-.442^{* * *} \\
(.000)\end{array}$ & $\begin{array}{l}-.010 \\
.727\end{array}$ & $\begin{array}{l}.071^{*} \\
(.014)\end{array}$ & $\begin{array}{l}.052 \\
(.074)\end{array}$ & $\begin{array}{l}-.030 \\
(.297)\end{array}$ & $\begin{array}{l}.005 \\
(.865)\end{array}$ & $\begin{array}{l}.005 \\
(.876\end{array}$ & $\begin{array}{l}-.406^{* * *} \\
.000\end{array}$ & & \\
\hline $\begin{array}{l}\text { 10. Intention to } \\
\text { inconspicuously 'Like' }\end{array}$ & $\begin{array}{l}-.402^{* * *} \\
(.000)\end{array}$ & $\begin{array}{l}.065^{*} \\
(.025)\end{array}$ & $\begin{array}{l}.114^{* * *} \\
(.000)\end{array}$ & $\begin{array}{l}.080^{* *} \\
(.006)\end{array}$ & $\begin{array}{l}.174^{*} \\
(.057)\end{array}$ & $\begin{array}{l}.000 \\
(.995)\end{array}$ & $\begin{array}{l}.039 \\
(.184)\end{array}$ & $\begin{array}{l}-.209^{* * *} \\
(.000)\end{array}$ & $\begin{array}{l}.709^{* * *} \\
(.000)\end{array}$ & \\
\hline
\end{tabular}


This article is (C) Emerald Publishing and permission has been granted for this version to appear here (repository.falmouth.ac.uk). Emerald does not grant permission for this article to be further copied/distributed or hosted elsewhere without the express permission from Emerald Group Publishing Limited. 